\title{
The Prevalence and Predictors of HIV Infection among Children of Mothers who Missed Prevention of Mother to Child Transmission of HIV Interventions in Makurdi, Nigeria
}

Emmanuel Adémólá Anígilájé ${ }^{1 \#}$, Othniel Joseph Dabit ${ }^{1}$, Bem Ageda ${ }^{2 \#}$, Stephen Hwande ${ }^{2}$ and Terkaa Terrumun Bitto ${ }^{3}$

${ }^{1}$ Department of Paediatrics, Benue State University, Makurdi, Benue State, Nigeria

${ }^{2}$ Department of Obstetrics and Gynecology, Federal Medical Centre, Makurdi, Benue State, Nigeria

${ }^{3}$ Department of Community Medicine, Benue State University, Makurdi, Benue State, Nigeria

\#Contributed equally and share first Authorship

\begin{abstract}
Introduction: In Nigeria, gaps between uptakes of Prevention of Mother To Child Transmission of HIV (PMTCT) interventions by HIV-infected women continue to exist with its consequent increase in perinatal HIV epidemic. This study aims to determine the predictors and HIV infection rates among infants and children of mothers of PMTCT Gaps in a major Nigerian city.

Methods: It is a retrospective study that involved infants and children seen at the Federal Medical Centre, Makurdi, between June 2009 and June 2011. The bivariate and multivariable logistic regression models were used to identify risk factors that may predict MTCT of HIV.

Results; A total of 224 subjects comprising 121 males $(M)$ and 103 females $(F)$ with a M: $F$ ratio of 1:0.9 was seen. The median age was 150 days with a range from 4 days to 690 days. MTCT of HIV was $34.4 \%(77 / 224)$. In multivariate analyses and after adjusting for other factors: absence of episiotomy at delivery (Adjusted Odd Ratio -AOR 0.063, $95 \% \mathrm{Cl}$ 0.005-0.773, $\mathrm{p}=0.031$ ), partial PMTCT interventions involving antiretroviral given to mothers and their babiesafter 72 hours of life, (AOR $0.050,95 \% \mathrm{Cl} 0.005-0.512, p=0.031$ ), mixed feeding (AOR 4.017, 95\% $\mathrm{Cl} 1.030-15.665$, $\mathrm{p}=0.045$ ), maternal HIV viral loads of $1001-10,000 \mathrm{copies} / \mathrm{ml}$ (AOR $3.207,95 \% \mathrm{Cl} 1.158-8.882, p=0.025$ ) and children presenting at older than 12 months of age (AOR 26.331,95\%Cl1.244-557.230, $p=0.036$ ) remain independently associated with HIV transmission.
\end{abstract}

Conclusion: The high prevalence of MTCT of HIV in the present study can be prevented if access, uptake and PMTCT interventions are improved.

Keywords: Prevalence; Predictors; HIV; MTCT; PMTCT-Gaps; Makurdi

\section{Introduction}

In 2008, an estimated 1.4 million HIV infected pregnant women living in low- and middle-income countries gave birth and $91 \%$ of these women reside in sub-Saharan Africa [1]. Without intervention, 25-40\% of infants born to HIV-positive mothers will become infected [2] and mother to child transmission of HIV (MTCT) is responsible for over $85 \%$ of paediatric HIV/AIDS [3,4]. With current interventions of Prevention of Mother to Child Transmission of HIV (PMTCT), this risk can be reduced to between 1-2\% [2]. The PMTCT program started in Nigeria in 2001 in 6 tertiary health facilities but has steadily increased to involve 1,320 sites spread across the 36 States of the country and its Capital, Abuja [5]. However, uptake of PMTCT interventions at these sites has been meagre, increasing from $11 \%$ in 2010 to $20.7 \%$ in 2012 [5] and Nigeria remains one of the 22 focus countries of the Global Plan to Eliminate MTCT [6]. The Nigeria National AIDS Control Agency (NACA) has rightly identified the challenges facing PMTCT to include poor uptake despite the availability of PMTCT services and commodities amongst others [5]. For example in Benue State where the study was done, there are currently 200 PMTCT sites spread across all the 23 local Government Areas, [7] with the Federal Medical Centre, (FMC) offering a tertiary level of PMTCT interventions in Makurdi, the state capital. Despite the availability of these facilities, the FMC continues to record HIV infected infants, whose mothers did not access, initiate and sustain PMTCT interventions. Although, the knowledge and documentation of the Preventers and Barriers of PMTCT services are important and are also being studied by the Authors, the present study focuses on the prevalence and risk factors of MTCT of HIV among infants and children whose mothers have missed or had a partial PMTCT intervention.

\section{Material and Methods}

\section{Study area and setting}

The study was carried out at the Paediatric ART (Antiretroviral therapy) Clinic of the Riverside Specialist Clinics of the FMC, Makurdi. The Centre is the only tertiary health hospital providing care and treatment for children exposed to or infected with HIV in Benue State. It provides paediatric HIV care and treatment in accordance with the Nigeria National Guidelines on Paediatric HIV/AIDS Treatment and Care. It is also a referral centre for primary and secondary health facilities in Benue State and the surrounding states of Taraba, Nasarawa, and Kogi. The facility is supported by the AIDS Prevention Initiative

*Corresponding author: Anígilájé EA, Department of Paediatrics, Benue State University, Makurdi, Benue State, Nigeria, Tel: +2348033833839; E-mail: demolaanigilaje@yahoo.co.uk

Received August 30, 2013; Accepted September 28, 2013; Published October 10, 2013

Citation: Anígilájé EA, Dabit OJ, Ageda B, Hwande S, Bitto TT (2013) The Prevalence and Predictors of HIV Infection among Children of Mothers who Missed Prevention of Mother to Child Transmission of HIV Interventions in Makurdi, Nigeria. J AIDS Clin Res 4: 249. doi: 10.4172/2155-6113.1000249

Copyright: ( 2013 EAnígilájé A, et al. This is an open-access article distributed under the terms of the Creative Commons Attribution License, which permits unrestricted use, distribution, and reproduction in any medium, provided the original author and source are credited. 
Citation: Anígilájé EA, Dabit OJ, Ageda B, Hwande S, Bitto TT (2013) The Prevalence and Predictors of HIV Infection among Children of Mothers who Missed Prevention of Mother to Child Transmission of HIV Interventions in Makurdi, Nigeria. J AIDS Clin Res 4: 249. doi: 10.4172/21556113.1000249

Page 2 of 7

in Nigeria (APIN) /Harvard PEPFAR (The USA President's Emergency Plan for AIDS Relief) program.

\section{Ethical consideration}

Ethical approval for the study was obtained from the Hospital Research and Ethics Committee. HIV-exposed and infected infants were recruited into care and treatment upon consent of their parents or caregivers.

\section{Study population}

It is a retrospective study that involved infants and children seen at FMC, Makurdi between June 2009 and June 2011. Study proforma was developed to retrieve relevant data that were routinely recorded in infants' Initial Visit Forms at recruitment and the last pre-delivery Follow-up Clinical Forms for mothers that attended antenatal care at the centre. Inclusion criteria included HIV-exposed babies older than 72 hours who were delivered to HIV-infected mothers. HIV infection may have been confirmed in these mothers before and during pregnancy, in labour and after delivery. Exclusion criteria included the receipt of blood transfusion and or those with a proven history of sexual abuse that may suggest horizontal mode of HIV transmission.

\section{Follow-up of HIV positive pregnant mothers and their infants and operational definitions}

Scheduled follow-up clinic attendances for HIV-exposed infants were as follows: every 2 -week for the first 6 weeks, every month for the first 3 months and thereafter, every 3 -month till the age of 18 months. Early infant diagnoses with the DNA/PCR were offered at the $6^{\text {th }}$ week and $3^{\text {rd }}$ month of life or at any time before the age of 18 months. Antibody diagnostic tests were applied for the infant presenting at and beyond 18 months of life. Universal co-trimoxazole prophylaxis was commenced for all infants from 6 weeks of life. Unscheduled visit took place at any time when diagnostic assessments of presenting problems were done. Infants with a confirmed HIV-infection were recruited into care and anti-retroviral therapy.

PMTCT Interventional guidelines for the mothers followed the 2004, 2006 and 2010 WHO [8] recommendations depending on the year of pregnancy and whether ANC and or delivery took place at FMC Makurdi (tertiary interventions) or at the referring primary and secondary PMTCT centers.

During the first ANC visit, all pregnant women received HIV testing and counseling and those found HIV-infected were screened for clinical and immunological eligibility for the commencement of ART. Mothers who were eligible received highly active antiretroviral therapy (HAART) regimen including Zidovudine (AZT) plus Lamivudine (3TC) plus Nevirapine (NVP) from 14 weeks of gestation. Mothers that were not qualified for HAART also receive ARV chemoprophylaxis including zidovudine (AZT) from 14 weeks and administration of single dose nevirapine (sdNVP) during labour and with Zidovudine plus Lamivudine also given for one week to cover the Nevirapine tail. Pregnant women starting prophylaxis at 33 weeks of gestation were given zidovudine (AZT) plus Lamivudine (3TC) and sdNVP taken during labour. Women newly diagnosed for HIV during labour received sdNVP alone which was followed with a week course of Zidovudine and Lamivudine combination. Zidovudine from gestational age of 14 weeks till delivery and single dose nevirapine during labour were the only option given at the primary and secondary health facilities referring to FMC Makurdi. Infantile prophylaxes for the HIV-exposed babies included daily doses of Nevirapine (NVP), commenced within the first
72 hours of life and given for the first 6 weeks of life or a single dose NVP at birth and zidovudine, commenced within the first 72 hours of life and given for the first 6 weeks of life. CD4+ lymphocyte count and HIV-1 ribonucleic acid (RNA) level were measured at scheduled visits during ANC for FMC Makurdi attendees.

Subjects are consecutive infants who met the inclusion criteria and did not access full PMTCT interventions. Access to full PMTCT interventions is strictly defined as a combination of the following: first, receipt of ARV medicine by HIV-infected pregnant women for their own HIV disease or for the purpose of PMTCT during antenatal care or in labor; second, HIV-exposed babies' receipt of ARV prophylaxes as described above. As previously categorized elsewhere [9], HIV-exposed or infected babies who did not access full PMTCT interventions would then include; (1) babies whose mothers received ARV prophylaxis/ treatment but had no ARV prophylaxes, (2) babies who received ARV prophylaxes while their mothers had no ARV prophylaxis/ treatment (3) babies whose mothers had ARV prophylaxis/treatment but receive ARV prophylaxes after 72 hours of age and (4) mother-baby pairs that did not receive ARV prophylaxis/treatment. For mothers who attended ANC at FMC Makurdi, pre-trained nurses provided education and training on mothers' informed choices of either breastfeeding or replacement feeding. A 6-month supply of commercial infant formula was offered free by the programme but dispensed to the mothers on a monthly prescription.

Exclusive breastfeeding (EBF) was defined as the infant receiving only breastmilk from birth to 6 months of age from his/her mother and no other liquids or solids, with the exception of drops or syrups consisting of vitamins, mineral supplements, or drugs [10]. Exclusive breastmilk substitute feeding (EBMS) was defined as provision of infant formula and the exclusion of all breastfeeding during the first 6 months of age [8]. Mixed breastfeeding (BF+BMS) was defined as giving breast milk with non-human milk or solids at any time during the first 6 months of age [10].

\section{Data collection and management}

The following relevant information from the subjects' Initial Visit Forms were obtained: age at presentation, gender, mothers' receipt of ARV prophylaxes/treatment or not, mode and place of delivery, presence of prolonged rupture of membrane of more than 4 hours, vaginal tear, episiotomy, gestational age at birth, birth weight, types of ARV prophylaxes in the infants, mothers' breast conditions, babies oral thrush/sore, history of breastfeeding/mixed feeding/exclusive breast milk substitute feeding and the anthropometric measures of weight and height . Anthropometric computations and comparisons were conducted using the WHO anthro software which is based on WHO child growth standards 2006 [11]. Underweight was defined as a weight for age $\mathrm{z}$-score (WAZ-score) less than -2 standard deviations (SD) from the WHO reference median values [11]. Stunting was defined as height for age $\mathrm{z}$-score (HAZ-score) less than -2SD from the reference values and weight for height $\mathrm{z}$-score (WHZ-score) less than -2SD from the WHO reference median defined wasting [11]. For mothers who attended ANC at FMC Makurdi, the last Follow-up Visit Forms before delivery were analysed for information such as the viral load, CD4 count, haemoglobin count, Hepatitis B surface antigen and Hepatitis $\mathrm{C}$ virus antibodies.

\section{Outcomes}

Outcomes of HIV-screening included HIV-infected infants defined as babies whose mothers are HIV-infected and had two positive 
Citation: Anígilájé EA, Dabit OJ, Ageda B, Hwande S, Bitto TT (2013) The Prevalence and Predictors of HIV Infection among Children of Mothers who Missed Prevention of Mother to Child Transmission of HIV Interventions in Makurdi, Nigeria. J AIDS Clin Res 4: 249. doi: 10.4172/21556113.1000249

Page 3 of 7

consecutive DNA/PCR results at the $6^{\text {th }}$ week and the $3^{\text {rd }}$ month of life for babies who presented before the $6^{\text {th }}$ week of life and two positive DNA/ PCR results for babies presenting to the health facility after the $6^{\text {th }}$ week of life and before the age of 18 months. Two negative consecutive DNA/ PCR results defined HIV-exposed un-infected babies delivered to HIVinfected mothers. When the first two DNA/PCR results are discordant, a $3^{\text {rd }}$ DNA/PCR confirms negativity or positivity. For subjects that are $\geq 18$ months, they had an initial double rapid HIV antibody tests using Determine HIV1/2 first and then HIV 1/2STATPAK in serial algorithm. HIV infection was then confirmed in subjects who had reactive rapid test by using a Western Blot test. Because the exposed infant's and children's HIV status was first assessed and documented between the ages of 4 days and 23 months at presentation, it was difficult to know precisely when HIV infection occurred.

\section{Statistical analysis}

Statistical analysis was done using SPSS version 16. Descriptive analysis was employed to describe the proportion of HIV-infected babies by age groups, gender and categories of babies that did not access or had a partial PMTCT. Baseline demographic characteristics were presented as proportions, medians with interquartile ranges (IQR), and means with standard deviations (SD). The bivariate and multivariable logistic regression models were used to identify a priori variables [12] that may predict MTCT of HIV (and other variables that may predict MTCT of HIV). These other variables include HIV-Hepatitis B and HIV-Hepatitis $\mathrm{C}$ virus co-infections in the mother, maternal anaemia, maternal marital and socioeconomic status. Others include number of children in the household as well as history of prior hospitalization in the children at presentation. Only variables with $p$ value of 0.1 at the bivariate analysis were considered for multivariate logistic regression. For all analyses, confidence intervals (CI) were set at the 95\% level and p-values less than 0.05 were considered statistically significant.

\section{Results}

\section{Some clinical and demographic characteristics of the subjects at presentation}

Table 1 shows that a total of 224 infants and children was seen during the period of study. Four infants were excluded having received blood transfusions at a primary health facility. Other 26 subjects did not have the complete records of data of interests. Out of the 224 subjects' studied, only 71 (31.7\%) attended ANC at FMC Makurdi. The remaining 153 mothers (68.3\%) were referred from both primary and secondary health centres from Benue and its surrounding states. The 224 subjects comprised 121 males (M) and 103 females (F) with an $\mathrm{M}$ : $\mathrm{F}$ ratio of 1:0.9. There were 5 twin-pairs. The median age was 150 days with a range from 4 days to 690 days. The mean Gestational Age (GA) was 39.22 weeks with a Standard Deviation of \pm 1.92 weeks. A total of 113 subjects (50.4\%) were stunted with a median HAZscore of -2.030 and Interquartile Range (IQR) of -3.645 to -0.553 . A little below half, $110(49.1 \%)$ subjects were underweight with a mean WAZ-score of -1.915 and a SD of \pm 2.14 . Wasting was only found among 68 subjects $(30.4 \%)$, with a median WHZ-score of -0.750 and IQR of -2.308 to 0.7150 .

A majority-216 (96.4\%) of the subjects was born via the vagina. Prolonged rupture of the membrane occurred among 93 subjects (41.5\%). Only one-third of the children had ARV prophylaxes including $42(18.8 \%)$ that had NVP for 6 weeks and $26(11.6 \%)$ that were given sdNVP at birth and ZDV for 6 weeks. MTCT of HIV was $34.4 \%$ (77/224) accruing from the 77 subjects that were HIV-infected.

\begin{tabular}{|c|c|}
\hline Characteristics & Number (\%) \\
\hline \multicolumn{2}{|l|}{ Gender } \\
\hline Male & $121(54.0)$ \\
\hline Female & $103(46.0)$ \\
\hline \multicolumn{2}{|l|}{ Age at presentation } \\
\hline Median age in days (IQR) & $150(30-330)$ \\
\hline$\leq 6$ weeks & $65(29.0)$ \\
\hline$>6$ weeks -6 months & $58(25.9)$ \\
\hline$>6$ months -12 months & $63(28.1)$ \\
\hline$>12$ months & $38(17.0)$ \\
\hline \multicolumn{2}{|l|}{ GA } \\
\hline Mean ( $\pm S D)$ & $39.22(1.92)$ \\
\hline$\geq 37$ weeks & $210(93.8)$ \\
\hline 37 weeks & $14(6.2)$ \\
\hline \multicolumn{2}{|l|}{ WAZ } \\
\hline Mean ( $\pm S D)$ & $-1.915(2.14)$ \\
\hline Underweight & $110(49.1)$ \\
\hline Not underweight & $114(50.9)$ \\
\hline \multicolumn{2}{|l|}{ HAZ } \\
\hline Median (IQR) & $-2.03(-3.65$ to 0.55$)$ \\
\hline Stunted & $113(50.4)$ \\
\hline Not stunted & $111(49.6)$ \\
\hline \multicolumn{2}{|l|}{ WHZ } \\
\hline Median (IQR) & $0.75(-2.31$ to 0.72$)$ \\
\hline Wasted & $68(30.4)$ \\
\hline Not wasted & $156(69.6)$ \\
\hline \multicolumn{2}{|c|}{ No. of children in the household } \\
\hline$\leq 4$ & $86(38.4)$ \\
\hline$>4$ & $138(61.6)$ \\
\hline \multicolumn{2}{|l|}{ Delivery type } \\
\hline Elective C/S & $2(0.9)$ \\
\hline Emergent C/S & $6(2.7)$ \\
\hline Vaginal & $216(96.4)$ \\
\hline \multicolumn{2}{|l|}{ ROM } \\
\hline$<4$ hours & $129(57.6)$ \\
\hline$\geq 4$ hours & $93(41.5)$ \\
\hline Nil & $2(0.9)$ \\
\hline \multicolumn{2}{|l|}{ ARV prophylaxis in Infants } \\
\hline NVP (6 weeks) & $42(18.8)$ \\
\hline sdNVP + ZDV (6 weeks) & $26(11.6)$ \\
\hline None & $156(69.6)$ \\
\hline \multicolumn{2}{|l|}{ HIV Screening outcome } \\
\hline Negative & $147(65.6)$ \\
\hline Positive & 77 (34.4) \\
\hline \multicolumn{2}{|l|}{ Mode of HIV screening } \\
\hline DNA/PCR & $215(95.9)$ \\
\hline RVST & $9(4.1)$ \\
\hline \multicolumn{2}{|l|}{ Sources of referral } \\
\hline FMC & $71(31.7)$ \\
\hline Private $1^{0}$ & 133 ( 59.4$)$ \\
\hline Government $1^{0}+2^{0}$ & $20(8.9)$ \\
\hline
\end{tabular}

C/S- Caesarean section, ROM= Rupture of membrane, RVST $=$ HIV antibody test $1^{0}=$ Primary health facility, $2^{0}=$ Secondary health facility

Table 1: Some clinical and demographic characteristics of subjects at presentation. 
Citation: Anígilájé EA, Dabit OJ, Ageda B, Hwande S, Bitto TT (2013) The Prevalence and Predictors of HIV Infection among Children of Mothers who Missed Prevention of Mother to Child Transmission of HIV Interventions in Makurdi, Nigeria. J AIDS Clin Res 4: 249. doi: 10.4172/21556113.1000249

Page 4 of 7

\section{Some characteristics of the 71 mothers that had ANC at FMC Makurdi}

Table 2 reveals that among the 71 mothers that attended ANC at FMC Makurdi, the mean CD4 count was $356.12 \pm 199.66$ with 16 (22.5\%) women having CD4 count of $\leq 200$ cells $/ \mathrm{mm}^{3}$. The median viral load was 65,026 copies/ml and IQR of 2848 to 386,846 copies/ $\mathrm{ml}$ and only $6(8.5 \%)$ mothers had undetectable viral load. The mean haemoglobin was $10.31 \mathrm{~g} / \mathrm{dl} \pm 1.65$ and $27(38 \%)$ were anemic. Hepatitis B surface antigen was positive in $9(12.7 \%)$ and Hepatitis $C$ antibodies in $3(4.2 \%)$ women. Most mothers-211 (94.2\%) were having a form of partner (husbands or co-habitants) at the time of the study and a similar number, 212 (94.6\%) was earning a monthly income below the Nigeria minimum wage of 8,000 Naira (an equivalent of 50 USD). At the time of presentation, 193 women $(86.2 \%)$ were alive and healthy, with 28 others being sick and 3 mothers had died. Breast abscess was reported in only one mother (0.4\%). ARV interventions among the 71 mothers included $44(62 \%)$ that had HAART and $27(38 \%)$ with ARV prophylaxis.

\begin{tabular}{|c|c|}
\hline Characteristics & Number (\%) \\
\hline \multicolumn{2}{|l|}{ HCV antibody } \\
\hline Positive & $3(4.2)$ \\
\hline Negative & $68(95.8)$ \\
\hline \multicolumn{2}{|l|}{ HBsAg } \\
\hline Positive & $9(12.7)$ \\
\hline Negative & $62(87.3)$ \\
\hline \multicolumn{2}{|l|}{ Anaemia } \\
\hline Mean Hgb $( \pm S D)$ & $10.31(1.65)$ \\
\hline $10 \mathrm{~g} / \mathrm{dl}$ & $27(38.0)$ \\
\hline$\geq 10 \mathrm{~g} / \mathrm{dl}$ & $44(62.0)$ \\
\hline \multicolumn{2}{|l|}{ Marital status } \\
\hline With partner & $211(94.2)$ \\
\hline Without partner & $13(508)$ \\
\hline \multicolumn{2}{|c|}{ Social- economic status } \\
\hline$\geq$ minimum wage & $12(5.4)$ \\
\hline$<$ Minimum wage & $212(94.6)$ \\
\hline \multicolumn{2}{|l|}{ Breast abscess } \\
\hline Yes & $1(0.4)$ \\
\hline No & $223(99.6)$ \\
\hline \multicolumn{2}{|l|}{ Health status } \\
\hline Alive and healthy & $193(86.2)$ \\
\hline Alive and sick & $28(12.5)$ \\
\hline Dead & $3(1.3)$ \\
\hline \multicolumn{2}{|l|}{ Viral load } \\
\hline Median (IQR) & $65,026(2848-386,846)$ \\
\hline Detectable & $65(91.5)$ \\
\hline Undetectable & $6(8.5)$ \\
\hline \multicolumn{2}{|l|}{ CD4Count } \\
\hline$>200$ & $55(77.5)$ \\
\hline$\leq 200$ & $16(22.5)$ \\
\hline \multicolumn{2}{|l|}{ ARV Interventions } \\
\hline HAART & $44(62)$ \\
\hline ARV & $27(38)$ \\
\hline
\end{tabular}

$\mathrm{HCV}=\mathrm{Hepatitis} \mathrm{C}$ virus, $\mathrm{HBsAg}=$ Hepatitis $\mathrm{B}$ surface antigen, $\mathrm{Hgb}=$ haemoglobin Table 2: Some characteristics of the 71 mothers that had ANC at FMC Makurdi.

\begin{tabular}{|l|c|c|c|c|c|}
\hline \multirow{2}{*}{ Characteristics } & \multicolumn{2}{|c|}{ HIV Status } & \multirow{2}{*}{ OR } & 95\%Cl & \multirow{2}{*}{ P value* } \\
\cline { 2 - 3 } CD4 Count & Positive \% & Negative \% & & & \\
\hline$>200$ & $18(32.7)$ & $37(67.3)$ & Ref & & \\
\hline$\leq 200$ & $11(68.8)$ & $5(31.2)$ & 0.24 & $0.065-0.855$ & 0.028 \\
\hline Viral load categories & & & & & \\
\hline$\leq 1000$ & 0() 0.0 & $6(100.0)$ & Ref & & \\
\hline $1001-10,000$ & $4(22.2)$ & $14(77.8)$ & 36.06 & $1.028-1265.00$ & 0.048 \\
\hline $10,001-100,000$ & $8(53.3)$ & $7(46.7)$ & 0.79 & $0.071-8.787$ & 0.847 \\
\hline$>100,000$ & $17(53.1)$ & $15(46.9)$ & NA & NA & NA \\
\hline Viral load & & & & & \\
\hline Undetectable & $0(0.0)$ & $6(100.0)$ & NA & NA & 0.90 \\
\hline Detectable & $29(44.6)$ & $36(55.4)$ & & & \\
\hline Hepatitis B & & & & & \\
\hline Negative & $24(38.7)$ & $38(61.3)$ & Ref & & \\
\hline Positive & $5(55.6)$ & $4(44.4)$ & 0.58 & $0.132-2.548$ & $0.470^{*}$ \\
\hline
\end{tabular}

No association was found for Hepatitis $C$, Maternal anaemia, Marital status and Socioeconomic status . ${ }^{*}=$ Yates's continuity correction done, NA= Not available. Table 3: Risk factors for HIV transmission during pregnancy.

\begin{tabular}{|l|c|c|c|c|c|}
\hline \multirow{2}{*}{ Characteristics } & \multicolumn{2}{|c|}{ HIV Status } & \multirow{2}{*}{ OR } & 95\%Cl & \multirow{2}{*}{ P value* } \\
\cline { 2 - 5 } Vaginal tear & Positive \% & Negative \% & & & \\
\hline No & $46(27.7)$ & $120(72.3)$ & Ref & & \\
\hline Yes & $31(53.4)$ & $27(46.6)$ & 0.38 & $0.198-0.723$ & 0.003 \\
\hline Episiotomy & & & & & \\
\hline No & $51(27.6)$ & $134(72.4)$ & Ref & & \\
\hline Yes & $26(66.7)$ & $13(33.3)$ & 0.21 & $0.099-0.450$ & $<0.001$ \\
\hline
\end{tabular}

No association was found for Prolonged Rupture of Membrane and Delivery types Table 4: Risk factors for HIV transmission during labour and delivery.

\section{Risk factors for HIV transmission during pregnancy}

Table 3 shows that HIV infection was associated with significantly increased odds of high viral load (1001-10,000), [OR=36.06; 95\%CI: $1.028,1265.00 ; \mathrm{p}=0.048]$. Maternal CD4 count of $>200$ is significantly protective against MTCT of HIV [OR=0.24; 95\%CI: 0.065, 0.855 ; $\mathrm{p}=0.028)$. Hepatitis $\mathrm{B}$ co-infection in the mothers was not associated with MTCT of HIV [OR=0.58; 95\%CI: 0.132, 2.548; $\mathrm{p}=0.470]$.

\section{Risk factors for HIV transmission during labour and delivery}

In Table 4, absence of vaginal tear was significantly protective against MTCT of HIV [OR=0.38; 95\%CI: 0.198, 0.723; $\mathrm{p}=0.003$ ] and so did absence of episiotomy with [OR $=0.21$; 95\%CI: $0.099,0.450$, $\mathrm{p}=0.001$.

\section{Some risk factors in babies, mode of feeding and partial PMTCT interventions}

In Table 5, among the HIV infected subjects, underweight was found in $68.8 \%(53 / 77)$, stunting was found in $61.0 \%(47 / 77)$ and wasting in $42.9 \%(33 / 77)$ of subjects. The absence of both oral thrush and underweight in subjects was found to significantly protect against HIV infection, with [OR=0.28; 95\%CI: $0.112,0.718 ; \mathrm{p}=0.008]$ and [OR=0.40; 95\%CI: 0.182, 0.854; $\mathrm{p}=0.018$ ], respectively. Conversely, HIV infection was associated with significantly increased odds of EBMS [OR=27. 83; 95\%CI: 9.770, 79.290; $\mathrm{p}=0.001$ ], Mixed Feeding [OR=59.64; 95\%CI: 
Citation: Anígilájé EA, Dabit OJ, Ageda B, Hwande S, Bitto TT (2013) The Prevalence and Predictors of HIV Infection among Children of Mothers who Missed Prevention of Mother to Child Transmission of HIV Interventions in Makurdi, Nigeria. J AIDS Clin Res 4: 249. doi: 10.4172/21556113.1000249

Page 5 of 7

\begin{tabular}{|c|c|c|c|c|c|}
\hline \multirow{2}{*}{ Characteristics } & \multicolumn{2}{|c|}{ HIV Status } & \multirow{2}{*}{ OR } & \multirow{2}{*}{$95 \% \mathrm{Cl}$} & \multirow{2}{*}{ P value* } \\
\hline & Positive $\%$ & Negative $\%$ & & & \\
\hline \multicolumn{6}{|l|}{ Age Group } \\
\hline$\leq 6$ weeks & $11(16.9)$ & $54(83.1)$ & Ref & & \\
\hline$>6$ weeks -6 months & $22(37.9)$ & $36(62.1)$ & ------ & ----- & ---- \\
\hline$>6$ months -12 months & $25(39.7)$ & $38(60.3)$ & 2.20 & $0.750-6.440$ & 0.151 \\
\hline$>12$ months & $19(50.0)$ & $19(50.0)$ & 3.50 & $1.120-10.900$ & 0.031 \\
\hline \multicolumn{6}{|l|}{ WAZ Score } \\
\hline Not underweight & $24(21.1)$ & $90(78.9)$ & Ref & & \\
\hline Underweight & $53(48.2)$ & $57(51.8)$ & 0.40 & $0.182-0.854$ & 0.018 \\
\hline \multicolumn{6}{|l|}{ HAZ Score } \\
\hline Not stunted & $30(27.0)$ & $81(73.0)$ & Ref & & \\
\hline Stunted & $47(41.6)$ & $66(58.4)$ & 0.77 & $0.360-1.631$ & 0.490 \\
\hline \multicolumn{6}{|l|}{ WHZ Scores } \\
\hline Not wasted & $44(28.2)$ & $112(71.8)$ & Ref & & \\
\hline Wasted & $33(48.5)$ & $35(51.5)$ & 0.53 & $0.265-1.058$ & 0.072 \\
\hline \multicolumn{6}{|l|}{ No. of hospitalization } \\
\hline Nil hospitalization & $40(27.6)$ & $112(72.4)$ & Ref & & \\
\hline $1-2$ & $32(46.4)$ & $37(53.6)$ & 2.63 & $0.721-9.555$ & 0.143 \\
\hline$>2$ & $5(50.0)$ & $5(50.0)$ & 1.16 & $0.307-4.358$ & 0.830 \\
\hline \multicolumn{6}{|l|}{ GA at birth } \\
\hline$\geq 37$ weeks & $76(36.2)$ & $134(63.8)$ & Ref & & \\
\hline$<37$ weeks & $1(7.1)$ & 13(92.9) & 7.37 & $0.946-57.465$ & 0.057 \\
\hline \multicolumn{6}{|l|}{ Oral thrush } \\
\hline No & $64(31.5)$ & $139(68.5)$ & Ref & & \\
\hline Yes & $13(61.9)$ & $8(38.1)$ & 0.28 & $0.112-0.718$ & 0.008 \\
\hline \multicolumn{6}{|l|}{ Mode of Feeding } \\
\hline EBF & $12(12.0)$ & $88(88.0)$ & Ref & & \\
\hline Mixed BMS+BF & $14(21.2)$ & $52(78.8)$ & 59.64 & $20.810-170.900$ & $<0.001$ \\
\hline EBMS & $51(87.9)$ & $7(12.1)$ & 27.83 & $9.770-79.290$ & $<0.001$ \\
\hline \multicolumn{6}{|l|}{ Partial PMTCT } \\
\hline Mother had \& baby After 72 hours & $1(5.0)$ & $19(95.0)$ & Ref & & \\
\hline Only mother had ART & $28(54.9)$ & $23(45.1)$ & 0.298 & $0.137-0.650$ & 0.002 \\
\hline Only baby had ART & $17(35.4)$ & $31(64.6)$ & 0.604 & $0.267-1.366$ & 0.226 \\
\hline Mother \& baby did not had ART & $31(29.5)$ & $74(70.5)$ & 6.660 & $0.804-55.147$ & 0.079 \\
\hline
\end{tabular}

No association was found for Breast abscess, Breast engorgement and No of children in the household. *= Yates's continuity correction done, GA=gestational age. No. of hospitalization $=$ Prior number of hospitalizations at presentation.

Table 5: Some risk factors in babies, mode of feeding and partial PMTCT interventions.

20.810, 170.900; $\mathrm{p}=0.001]$ and those subjects that presented at age of $>12$ months [OR=3.50; 95\%CI: $1.120,10.900 ; \mathrm{p}=0.031]$. Subjects who had EBMS were more infected, $87.9 \%$ (51/58), followed by those with Mixed BMS +BF, 21.2\% (14/66) and EBF 12\% (12/100). The HIV infection rate was also found to increase progressively with age of subjects at presentation: $\leq 6$ weeks $(16.9 \%)$, $>6$ weeks- 6 months (37.9\%), >6 months- 12 months (39.7\%) and > 12 months (50.0\%)

\section{Multivariate analysis of the risk factors for HIV transmission}

In Table 6, in multivariate analyses and adjusting for WAZ, mother's CD4 count, vaginal tears, episiotomy, partial PMTCT Intervention, Oral thrush, Mode of feeding, Mother's Viral Load, Age groups, WHZ and GA, only episiotomy, partial PMTCT interventions, mode of feeding, mothers' viral load and age at presentation of the subjects remained independently associated with HIV infection. The odds ratio of transmission for women that did not have an episiotomy compared to those that had it was 0.063 ( $95 \% \mathrm{CI}, \mathrm{p}=0.031$ ). The odds ratio was 0.050 (95\% CI, p=0.012) when both mothers and their babies had ARV -after 72 hours -compared to when only mothers had ARV for PMTCT intervention. Conversely, the odds ratio of transmission for HIV increased 4.017-fold for children that were fed on EBMS and those that had mixed BMS+BF compared to those with EBF. The odds ratio of transmission of HIV increased 3.207-fold when pre-delivery maternal HIV RNA levels is within 1001-10,000 compared to viral load $\leq 1000$. Lastly, the odd ratio increased 26.331-fold when children presented at $>$ 12 months compared to when they presented at $\leq 6$ weeks of life.

\section{Discussion}

Among the 20 Global Plan Priority Countries, Nigeria had shown a slow decline of $8 \%$ of new HIV infection among children between 2009 
Citation: Anígilájé EA, Dabit OJ, Ageda B, Hwande S, Bitto TT (2013) The Prevalence and Predictors of HIV Infection among Children of Mothers who Missed Prevention of Mother to Child Transmission of HIV Interventions in Makurdi, Nigeria. J AIDS Clin Res 4: 249. doi: 10.4172/21556113.1000249

Page 6 of 7

\begin{tabular}{|l|c|c|c|}
\hline Characteristics & AOR & $\begin{array}{c}\text { Multivariate } \\
\text { P-value }\end{array}$ & $\mathbf{9 5 \%} \mathbf{~ C l}$ \\
\hline WAZ & 0.425 & 0.415 & $0.054-3.330$ \\
\hline Mother's CD4 count & 0.394 & 0.389 & $0.047-3.277$ \\
\hline Vaginal tear & 0.931 & 0.953 & $0.089-9.764$ \\
\hline Episiotomy & $\mathbf{0 . 0 6 3}$ & 0.031 & $0.005-0.773$ \\
\hline PMTCT Intervention & 0.050 & 0.012 & $0.005-0.512$ \\
\hline Oral thrush & 0.093 & 0.179 & $0.003-2.969$ \\
\hline Mode of feeding & 4.017 & 0.045 & $1.030-15.665$ \\
\hline Viral Load categories & 3.207 & 0.025 & $1.158-8.882$ \\
\hline Age groups & 26.331 & 0.036 & $1.244-557.230$ \\
\hline WHZ & 0.453 & 0.514 & $0.042-4.888$ \\
\hline GA & NA & NA & NA \\
\hline
\end{tabular}

\section{NA=Not available}

Table 6: Multivariate analysis of the risk factors for HIV transmission.

and 2012 [6]. Also, Nigeria has the largest number of children acquiring HIV infection - nearly 60000 in 2012, a number that has remained largely unchanged since 2009 [6]. Furthermore, $80 \%$ of HIV infected pregnant women did not receive antiretroviral medicines for PMTCT and the same $80 \%$ of women or infants did not receive ARV medicines during breastfeeding to prevent MTCT of HIV [6]. Without urgent action in Nigeria, the global target of a decline of $50 \%$ of new paediatric HIV infection sets for between 2009 and 2015 is unlikely to be reached.

The high prevalence of MTCT of HIV of $34.4 \%$ occurring among mothers-infants pairs with no or sub-optimal access and uptake of PMTCT interventions is instructive as the study was carried out in Benue State, one of the $12+1$ states, which had consistently contributed immensely to the high burden of HIV in Nigeria [6]. Benue state, located in the North Central region of Nigeria had the highest survey of HIV prevalence of $12.7 \%$ in 2010 [13].

However, the MTCT rate of $34.4 \%$ in this study was lower than; $73.7 \%$ of HIV infection in Eastern India [14], 67.7\% in Abakiliki [15], $69.6 \%$ in Jos [16], but higher than $30.0 \%$ reported from Enugu [17]. In Africa, geographical differences in the prevalence and rate of MTCT of HIV have been linked to the circulating viral genotypes in different areas with subtype B found predominantly in countries reporting lower MTCT rates of HIV and non-B subtypes and recombinant forms (CRFs) having a higher efficiency of MTCT [18-21].

It has been well established that MTCT of HIV can occur during pregnancy, labour and delivery and during breastfeeding and that in the absence of any intervention; the rate of MTCT is about $15 \%-25 \%$ among non-breastfeeding populations in North America and Europe and $25 \%-40 \%$ among breastfeeding populations in resource-limited countries [2]. However, with intervention, the MTCT rate can be reduced to as low as $2 \%$ [2]. It becomes obvious that the burden of new paediatric HIV infection that will continue to see in Nigeria and other Sub-Saharan countries are due to failure in accessing the PMTCT interventions.

The median age of presentation of subjects in the present study was 150 days with a range from 4 days to 690 days. Whereas, it is expected that babies are born in facilities where they can be given ARV prophylaxis for PMTCT within the first 72 hours of life. This delay in presentation contributes to the inaccessibility of PMTCT intervention in our cohort.

The odds ratio of transmission for women that did not have an episiotomy compared to those that had it was 0.063 ( $95 \% \mathrm{CI}, \mathrm{p}=0.031$ ). Sebitoloane et al. [22] had also reported that episiotomy was associated

with a two-fold increased risk of postpartum infections among the HIV-positive women. Although, avoidance of episiotomy is a standard care during delivery for PMTCT [12], unfortunately, most deliveries in this study took place at private primary health centres (more than half, 59.4\%) where the application of this knowledge may be sub-optimal. Similarly, poor application of standard care during deliveries for the prevention of HIV transmission was also noticed in Indian private health facilities $[23,24]$.

We also found that some sub-optimal PMTCT interventions protects against HIV transmission as the odds ratio was $0.050(95 \%$ $\mathrm{CI}, \mathrm{p}=0.012$ ) when both mothers had ARV and their babies also had ARV, albeit after 72 hours compared to when only the mother had ARV. Providing ARV prophylaxis for the newborn infant is intended to "mop up" circulating virus that may have been transmitted in spite of maternal ARV prophylaxis or treatment; and it is expected to be given within the first 72 hours of life. We proposed that ARV prophylaxes given to infants who presented shortly after 72 hours of life may still offer some protection against MTCT of HIV.

We also found that the odds ratio of transmission for HIV increased 4 -fold for children that were fed on EBMS and those that had mixed BMS + BF compared to those with EBF. Also only $12 \%$ of babies that had EBF were HIV infected against $21.2 \%$ among those on mixed feeding and $87.9 \%$ of those on "EBMS". Our findings tend to support the WHO 2010 guideline which recommends that provided the mother and/or baby is receiving ARVs for their health or as prophylaxis, exclusive breastfeeding should be practiced by HIV-infected mothers for the first six months of life [25]. Although, a continuous infant feeding counselling at scheduled visits was in place and BMS were provided free of charge by our program at FMC, Makurdi, we cannot be too sure if mixed feeding has not taken place among these cohorts on "EBMS". Oladokun et al. in Ibadan also reported that although the choice of BMS was $93.5 \%$ among the women interviewed, 3.7\% actually practiced mixed feeding [26]. In the community of study, stigmatization and social pressure from relatives are contending factors that may pressurize a woman to mix feed even when BMS are provided free. Buskens et al. in South Africa had also reported that both relatives and breadwinner have influence and even authority over options and modes of infant feeding [27]. Nevertheless, the increased risk that mixed feeding posed on HIV transmission has been reported by several studies $[29,30]$.

The odds ratio of transmission of HIV increased 3.207-fold when pre-delivery maternal HIV RNA levels is within 1001-10,000 compared to viral load $\leq 1000$. The proportion of subjects with HIV infection was also found to increase with pre-delivery maternal viral load; $0 \%$ for those with viral load $\leq 1000,22.2 \%$ (1001-10,000), 53.3\% (10,001$100,000)$ and $53.1 \%$ for those greater than 100,000 . Similar proportions of HIV infection were reported by Garcia et al. [31] including $0 \%$ for viral load 1000, $16.6 \%(1000-10,000), 52.2 \%(10,001-100,000)$ and $40.6 \%$ of viral load greater than 100,000 . John and Kreiss [32], as well as Mofenson et al. [33] in the 1990s have linked high levels of maternal viral HIV RNA to a higher risk of MTCT of HIV. In fact, the earlier realization of this link was part of the basis for the use of ARV drugs to lower maternal HIV viral load during pregnancy, labour and delivery [12].

Lastly, the odd ratio increased 26.331-fold when children presented at $>12$ months compared to when they presented at $\leq 6$ weeks of life. The HIV infection rate was also found to increase progressively at an older age of subjects. This finding tends to support the fact that the earlier HIV-exposed babies are brought to the health facility, the more feasible it is for ARV prophylaxis to be given and the better results we 
Citation: Anígilájé EA, Dabit OJ, Ageda B, Hwande S, Bitto TT (2013) The Prevalence and Predictors of HIV Infection among Children of Mothers who Missed Prevention of Mother to Child Transmission of HIV Interventions in Makurdi, Nigeria. J AIDS Clin Res 4: 249. doi: 10.4172/21556113.1000249

Page 7 of 7

get in PMTCT. We have already seen that even when ARV prophylaxis was given to infants who were older than 72 hours, some protection against HIV transmission was possible. Some of the reasons which made the presentation of infants within 72 hours of life impossible have already been discussed earlier.

We did not find any significant association between HIV-HBV co-infection and risk of MTCT of HIV even though systemic coinfections like HBV have been shown to increase the risk for motherto-child transmission of HIV (MTCT) via stimulation and the release of cytokines and inflammatory agents that enhance HIV replication systemically which then weaken the natural defenses to MTCT [34].

In conclusion, our study would add up to indicate that the practice of episiotomy, partial PMTCT interventions, mode of feeding of infants , mothers' viral load and age at presentation of the subjects remained independently associated with HIV infection, when adjusted for other risk factors of MTCT of HIV.

The findings of the study have been passed forward to Benue State AIDS Control Agency (BENSACA) and firm positive actions are being taken to increase the access, the up-take and the sustenance of PMTCT activities in the state

\section{Acknowledgment}

The authors would like to acknowledge and thank all the patients and staff of the APIN/Harvard PEPFAR program at the Federal Medical Centre, Makurdi, Benue State, Nigeria. A special thanks goes to Dr. J. Abah, the Principal Coordinator of the program.

\section{References}

1. World Health Organization, UNAIDS, United Nations Children's Fund (2009) Towards Universal access: scaling up priority HIVIAIDS interventions in the health care sector. Progress report, World Health Organization, Geneva, Switzerland.

2. Malyuta R, Newell ML, Ostergren M, Thorne C, Zhilka N (2006) Prevention of mother-to-child transmission of HIV infection: Ukraine experience to date. Eur J Public Health 16: 123-127.

3. Tindyebwa D, Kayita J, Musoke P, Eley B, Nduati R (2005) Handbook of AIDS in Africa by the African Network for the care of children affected by AIDS. ( $2^{\text {nd }}$ Edn.), 33-50.

4. Schreiber GB, Busch MP, Kleinman SH, Korelitz JJ (1996) The risk of transfusion-transmitted viral infections. The Retrovirus Epidemiology Donor Study. N Engl J Med 334: 1685-1690.

5. National Agency for the Control of AIDS (NACA) (2012) Fact Sheet: PMTCT in Nigeria.

6. UNAIDS (2013) 2013 progress report on the Global Plan towards the elimination of new HIV infections among children by 2015 and keeping their mothers alive.

7. Benue State AIDS Control Agency (2013) Fact Sheet: Role out of PMTCT sites.

8. Gourlay A, Birdthistle I, Mburu G, lorpenda K, Wringe A (2013) Barriers and facilitating factors to the uptake of antiretroviral drugs for prevention of motherto-child transmission of HIV in sub-Saharan Africa: a systematic review. J Int AIDS Soc 16: 18588.

9. Ugochukwu EF, Kanu SO (2010) Early infant diagnosis of HIV infection in southeastern Nigeria: prevalence of HIV infection among HIV-exposed babies. West Afr J Med 29: 3-7.

10. WHO (2006) HIV and Infant Feeding: New evidence and programmatic experience. Report of a technical consultation held on behalf of the Interagency Task Team (IATT) on Prevention of HIV infections in pregnant women, Mother and their Infants, Geneva, Switzerland.

11. WHO (2011) WHO Anthro for personal computers, version 3.2.2, 2011 Software for assessing the growth and development of the world's children, Child growth standards.

12. Prevention of Mother-to-Child Transmission of HIV (2010) Expert Pane Report and Recommendations to the U.S. Congress and U.S. Global AIDS Coordinator.
13. Federal Ministry of Health (2012) National HIV Sero-prevalence Sentinel Survey.

14. Guha P, Sardar P (2011) Prevalence of Paediatric HIV Infection in Eastern India-First report. J AIDS Clinic Res 2: 127.

15. Ojukwu JU, Ogbu CN (2007) HIV infection in hospitalized children with endemic diseases in Abakaliki, Nigeria: the role of clinically directed selective screening in diagnosis. AIDS Care 19: 330-336.

16. Angyo IA, Okpeh ES, Onah J (1998) Paediatric AIDS in Jos, Nigeria. West Afr J Med 17: 268-272.

17. Emodi IJ, Okafor GO (1998) Clinical manifestations of HIV infection in children at Enugu, Nigeria. J Trop Pediatr 44: 73-76.

18. Murray MC, Embree JE, Ramdahin SG, Anzala AO, Njenga S, et al. (2000) Effect of human immunodeficiency virus (HIV) type 1 viral genotype on motherto-child transmission of HIV-1. J Infect Dis 181: 746-749.

19. Renjifo B, Fawzi W, Mwakagile D, Hunter D, Msamanga G, et al. (2001) Differences in perinatal transmission among human immunodeficiency virus type 1 genotypes. J Hum Virol 4: 16-25.

20. Yang C, Li M, Newman RD, Shi YP, Ayisi J, et al. (2003) Genetic diversity of HIV-1 in western Kenya: subtype-specific differences in mother-to-child transmission. AIDS 17: 1667-1674.

21. Odaibo GN, Olaleye DO, Heyndrickx L, Vereecken K, Houwer K, et al. (2006) Mother-to-child transmission of different HIV-1 subtypes among ARV Naïve infected pregnant women in Nigeria. Rev Inst Med Trop Sao Paulo 48: 77-80.

22. Sebitloane HM, Moodley J, Esterhuizen TM (2009) Determinants of postpartum infectious complications among HIV uninfected and antiretroviral naïve-HIV infected women following vaginal delivery: a prospective cohort study. Eur $J$ Obstet Gynecol Reprod Biol 145: 158-162.

23. Merchant RH, Damania K, Gilada IS, Bhagwat RV, Karkare JS, et al. (2001) Strategy for preventing vertical transmisssion of HIV : Bombay experience. Indian Pediatr 38: 132-138.

24. Merchant RH, Changedia S (1997) Prevention of vertical transmission of human immunodeficiency virus. Indian Pediatr 34: 475-480.

25. Hirnschall G, Harries AD, Easterbrook PJ, Doherty MC, Ball A (2013) The next generation of the World Health Organization's global antiretroviral guidance. $J$ Int AIDS Soc 16: 18757.

26. Oladokun RE, Brown BJ, Osinusi K (2010) Infant-feeding pattern of HIV-positive women in a prevention of mother-to-child transmission (PMTCT) programme. AIDS Care 22: 1108-1114.

27. Buskens I, Jaffe A, Mkhatshwa $H$ (2007) Infant feeding practices: realities and mind sets of mothers in Southern Africa. AIDS Care 19: 1101-1109.

28. Coutsoudis A (2000) Influence of infant feeding patterns on early mother-tochild transmission of HIV-1 in Durban, South Africa. Ann N Y Acad Sci 918: 136-144.

29. Coovadia HM, Rollins NC, Bland RM, Little K, Coutsoudis A, et al. (2007) Mother-to-child transmission of HIV-1 infection during exclusive breastfeeding in the first 6 months of life: an intervention cohort study. Lancet 369: 1107-1116.

30. Iliff PJ, Piwoz EG, Tavengwa NV, Zunguza CD, Marinda ET, et al. (2005) Early exclusive breastfeeding reduces the risk of postnatal HIV-1 transmission and increases HIV-free survival. AIDS 19: 699-708.

31. Garcia PM, Kalish LA, Pitt J, Minkoff H, Quinn TC, et al. (1999) Maternal levels of plasma human immunodeficiency virus type 1 RNA and the risk of perinatal transmission. Women and Infants Transmission Study Group. N Engl J Med 341: 394-402.

32. John GC, Kreiss J (1996) Mother-to-child transmission of human immunodeficiency virus type 1. Epidemiol Rev 18: 149-157.

33. Mofenson LM (1994) Epidemiology and determinants of vertical HIV transmission. Sem Pediatr Infect Dis 5: 252-256.

34. King CC, Ellington SR, Kourtis AP (2013) The role of co-infections in mother-tochild transmission of HIV. Curr HIV Res 11: 10-23. 